University of Nebraska - Lincoln

DigitalCommons@University of Nebraska - Lincoln

Faculty Publications: Department of Entomology

Entomology, Department of

2009

\title{
Amplified fragment length polymorphism used for inter- and intraspecific differentiation of screwworms (Diptera: Calliphoridae)
}

\author{
L. Alamalakala \\ University of Nebraska-Lincoln \\ Steven R. Skoda \\ University of Nebraska-Lincoln, sskoda1@unl.edu \\ John E. Foster \\ University of Nebraska-Lincoln, john.foster@unl.edu
}

Follow this and additional works at: https://digitalcommons.unl.edu/entomologyfacpub

Part of the Entomology Commons

Alamalakala, L.; Skoda, Steven R.; and Foster, John E., "Amplified fragment length polymorphism used for inter- and intraspecific differentiation of screwworms (Diptera: Calliphoridae)" (2009). Faculty Publications: Department of Entomology. 173.

https://digitalcommons.unl.edu/entomologyfacpub/173

This Article is brought to you for free and open access by the Entomology, Department of at DigitalCommons@University of Nebraska - Lincoln. It has been accepted for inclusion in Faculty Publications: Department of Entomology by an authorized administrator of DigitalCommons@University of Nebraska - Lincoln. 


\title{
Amplified fragment length polymorphism used for inter- and intraspecific differentiation of screwworms (Diptera: Calliphoridae)
}

\author{
L. Alamalakala ${ }^{1}$, S.R. Skoda ${ }^{2 *}$ and J.E. Foster ${ }^{1}$ \\ ${ }^{1}$ Department of Entomology, Insect Genetics Laboratory, University of \\ Nebraska, Lincoln, Nebraska 68583-0816, USA: ${ }^{2}$ USDA-ARS-SRU, \\ American Embassy, PSC 2 Box 4178, APO, AA 34002
}

\begin{abstract}
Morphologically, early immature stages of the economically important pest called screwworms, Cochliomyia hominivorax (Coquerel) (Diptera: Calliphoridae), and non-pest secondary screwworms, Cochliomyia macellaria (Fabricius) (Diptera: Calliphoridae), are nearly indistinguishable. Correct identification is crucial to the ongoing eradication and exclusion program protecting the United States, Mexico and Central America from reinvasion of screwworms persistent in South America and the Caribbean. Amplified fragment length polymorphism (AFLP) polymerase chain reaction was used to differentiate populations of $C$. hominivorax and to discriminate them from C. macellaria. Ten primer pairs screened for interspecific discrimination of $C$. hominivorax from $C$. macellaria showed 52 discrete bands, allowing the two species to be readily distinguished; divergent branches on resulting dendrograms showed $100 \%$ bootstrap support. C. macellaria populations grouped at the $92 \%$ level; $C$. hominivorax populations grouped at the $68 \%$ level. Of the 52 bands, seven were monomorphic for both species, 22 were specific to C. macellaria, ten were present only in C. hominivorax and the remaining 13 bands differentiated C. hominivorax populations. Separate studies using ten strains of C. hominivorax showed a higher level of genetic similarity within than between populations. Analyses using 72 bands (19 monomorphic bands, 53 bands grouped all ten strains at the $58 \%$ similarity level) resolved seven mutant strains from Mexico (85\% similarity level); all ten strains were resolved at the $72 \%$ similarity level. Diagnostic bands were identified for species and strain identification. We conclude that AFLP can be a valuable tool for studies of interspecific and intraspecific genetic variation in screwworm populations.
\end{abstract}

Keywords: AFLP, C. hominivorax, C. macellaria, genetic similarity

(Accepted 12 May 2008)

*Author for correspondence

Fax: 011(507) 296-0969

E-mail: steve.skoda@ars.usda.gov

\section{Introduction}

Larvae of the screwworm, Cochliomyia hominivorax (Coquerel) (Diptera: Calliphoridae), are obligate parasites of endothermic vertebrates that caused economic losses estimated to exceed $\$ 1$ billion annually before their eradication from the United States, Mexico and most of Central America by using the sterile insect technique (SIT) (Vargas-Terán 
et al., 2005). Screwworms remain a threat to domestic animals and wildlife, as well as humans, in regions of their current distribution, part of the Caribbean and all of South America (with the exception of Chile) (Wyss \& Galvin, 1996). Major challenges to the eradication effort include monitoring the progress of eradication in zones under treatment with sterile flies, detecting reinfestations in screwworm-free zones and monitoring the area surrounding the mass production facilities for the escape of fertile flies. Consequently, effective monitoring, surveillance and quarantine methods should be adopted because sporadic outbreaks and reintroduction of this pest to the previously eradicated regions (southwestern United States and Mexico), as well as new geographical regions (Libya, Australia, and France), by livestock trade or human travel have threatened the efficacy of SIT (Chermette, 1989; Hall \& Beesley, 1990; Searson et al., 1992; Narang \& Degrugillier, 1995).

Additionally, the secondary screwworm, Cochliomyia macellaria (Fabricius) (Diptera: Calliphoridae), shows morphological similarity and overlap in geographic distribution with C. hominivorax. C. macellaria also coexists with C. hominivorax in the same infested wound, thereby contributing to numerous misidentifications (Leite \& Guevara, 1993; Litjens et al., 2001). Cochliomyia macellaria is a saprophagous species that feeds primarily on carrion and is a secondary agent of myiasis (Litjens et al., 2001). Therefore, it is important to investigate novel and reliable methods for correct identification of these two species because of the possibility of sabotage or fraud for outbreak samples (in one case, emergency release of sterile flies had been made on samples that proved negative on subsequent analysis: Anonymous, 1990). A rapid, simple and easily interpretable screening system that can distinguish closely related insect species would speed research on wild populations and improve insect control decisions. A blocking enzyme-linked immunosorbent assay, based on monoclonal antibodies against screwworm antigens, was developed that differentiated screwworm eggs, larvae, pupae and adults from those of the secondary screwworm, as well as Phormia regina (Meigen), Lucilia sericata Meigen, Calliphora vicina Robineau-Desvoidy and Chrysomya rufifacies (Macquart) (Figarola et al., 2001). However, apart from the development of a monoclonal antibody-based assay, the ability of DNA markers for identification also needs to be explored.

Currently, screwworm eradication programmes rely heavily on the use of SIT. A major constraint to the eradication effort is the limited amount of information regarding the population structure for implementing SIT. Therefore, assessment of the genetic population structure of the screwworm pest will be valuable to the success of the eradication program (Bram, 1985; FAO, 1992). It is not known whether the populations of $C$. hominivorax in South America are the 'same' as in Central America, i.e. whether the populations are related or isolated. These questions are important because, if there is mating isolation, eradication could not occur if an inappropriate strain was reared and released. Therefore, if the wrong strain was being reared the program would fail because of assortative mating and failure of sterile males to mate with native females.

The questions of population structure, identification and differentiation of $C$. hominivorax from $C$. macellaria and other related blow fly larvae can, to a large extent, be resolved using molecular genetic tools. Molecular genetic markers represent a powerful tool for identifying source populations in cases of reintroduction, outbreak, sabotage or biological warfare/terrorism. The overall objective of this study was to assess the genetic variability and to develop reliable DNA fingerprints for $C$. hominivorax (an obligatory pest) and C. macellaria (a facultative parasite) by using polymerase chain reaction (PCR)-based molecular markers.

Studying the population structure of an insect species helps in understanding the influence of genetic processes such as mutation, migration and selection on insect biology, behavior, ecology and evolution (Roderick, 1996). In insects where autocidal biological control has been implemented to control pest populations, knowledge of insect population structure and distributional ecology can contribute to the development of elite strains for large-scale deployment. Population structure consists of deciphering the genetic relationships among individuals within and between subpopulations and, thus, assessing the genetic variation among individuals in a population (Leung et al., 1993). Advances in DNA marker technology in the past three decades have provided the necessary tools for systematists and population geneticists to use common approaches to study both intraspecific and interspecific variation in insect populations (Avise, 1994). Amplified fragment length polymorphism (AFLP) is a powerful technique that detects molecular genetic variations in DNA of any source or complexity without a priori knowledge of genome structure or sequence (Vos et al., 1995). The 'AFLP fingerprints' combine the reliability of restriction fragment length polymorphisms (RFLPs) and the power of PCR in a single technique, i.e. they are actually RFLPs visualized after selective PCR amplification of DNA restriction fragments (Vos et al., 1995). Therefore, analysis of AFLPs has the potential to become a powerful DNA fingerprinting technique for studying genetic relationships and genetic diversity in arthropods (Reineke et al., 1999; Bensch \& Åkesson, 2005). AFLP analysis has been used to study geographic populations of gypsy moth, Lymantria dispar (Linnaeus) (Reineke et al., 1999), to assess the biodiversity of the midge Orseolia oryzae (Wood-Mason) (Katiyar et al., 2000), to determine differences in fall armyworm, Spodoptera frugiperda (J.E. Smith), based on host strains (McMichael \& Pashley, 1999) and its genetic variation (Clark et al., 2007); and to study honey bee, Apis mellifera L., population genetics (Suazo \& Hall, 1999). Here, we explore the utility of AFLP both to assess the degree of similarity and differentiate populations of $C$. hominivorax from different geographic regions and also to distinguish them from the morphologically similar calliphorid C. macellaria.

\section{Materials and methods}

\section{Insect samples}

All screwworm and secondary screwworm populations / strains used in this study were obtained from laboratory colonies reared at the USDA-ARS Midwest Livestock Insects Research Unit (MLIRU) Biosecure Screwworm Rearing Laboratory in Lincoln, Nebraska, USA. Specimens included third instars of C. macellaria samples from Nebraska, USA (CM), and third instars of $C$. hominivorax larvae representing four locations (Panama, PN and C9; Costa Rica, CR; Jamaica, JA; and Mexico, MX, CE, LH, LM, RL, and CN) (table 1). Samples were frozen and stored at $-80^{\circ} \mathrm{C}$ before DNA extraction. 
Table 1. Country of origin, approximate year of collection, code and important characteristics of screwworm populations studied.

\begin{tabular}{lllll}
\hline Species & Country of origin & $\begin{array}{c}\text { Year } \\
\text { collected }\end{array}$ & Code & \multicolumn{1}{c}{ Comments } \\
\hline $\begin{array}{l}\text { C. macellaria } \\
\text { C. hominivorax }\end{array}$ & Lincoln, NE, USA & $1996-1997$ & CM & Secondary screwworm \\
P95 & Panama & 1995 & PN & Wild type \\
CR92 & Costa Rica & 1992 & CR & Wild type \\
J98 & Jamaica $_{\text {PA34 }}^{\text {Mexico }}$ & 1998 & JA & Wild type \\
CECH & Mexico $^{\text {a }}$ & 1984 & MX & Orange eye mutant \\
C9 & Panama $_{\text {LH }}$ & 1985 & CE & Red eye mutant \\
LIMON & Mexico $^{\text {a }}$ & 1995 & C9 & White eye mutant \\
RL & Mexico $^{\text {a }}$ & 1984 & LH & Yellow eye mutant \\
CN & Mexico $^{\text {a }}$ & 1984 & LM & Green eye mutant \\
\hline
\end{tabular}

a Flies from Mexico had the following geographic origins: PA34 - Chiapas, MX; CECH Quintana Roo, MX; LH - Oaxaca, MX; Limon - Palenque, MX; RL - cross of LH and Limon; $\mathrm{CN}$ - cross between Chiapas and Oaxaca, MX.

Table 2. Oligonucleotide adapters and primers used for AFLP analysis.

\begin{tabular}{lll}
\hline Primer ID & \multicolumn{1}{c}{ Primer type } & \multicolumn{1}{c}{ Sequence $\left(5^{\prime}-3^{\prime}\right)$} \\
\hline EcoRI-F & Forward adapter & CTCGTAGACTGCGTACC \\
EcoRI-R & Reverse adapter & AATTGGTACGCAGTCTAC \\
MseI-F & Forward adapter & GACGATGAGTCCTGAG \\
MseI-R & Reverse adapter & TACTCAGGACTCAT \\
$\mathrm{E}(\mathrm{N}+0)$ & EcoRI Preamp primer & GAC TGC GTA CCA ATT C \\
$\mathrm{M}(\mathrm{N}+1)$ & Msel Preamp primer & GAT GAG TCC TGA GTA AC \\
$\mathrm{E}(\mathrm{N}+0+3)$ & EcoRI selective primer & GAC TGC GTA CCA ATT C NNN* \\
$\mathrm{M}(\mathrm{N}+1+2)$ & MseI selective primer & GAT GAG TCC TGA GTA ACNN \\
\hline
\end{tabular}

* $N$ represents the position of $(+3$ and +2$)$ selective nucleotides in the primer and may be either A, T, G or C.

\section{DNA isolation}

DNA was isolated from individually frozen insect samples by using a modified Black \& Duteau (1997) cetyltrimethylammonium bromide (CTAB) extraction protocol. The gut was removed and the larvae were homogenized in $500 \mu \mathrm{l}$ of extraction buffer $(100 \mathrm{mM}$ Tris- $\mathrm{HCl}, \mathrm{pH} 8.0,1.4 \mathrm{M}$ $\mathrm{NaCl}, 0.02 \mathrm{M}$ EDTA, 2\% CTAB and $0.2 \% \beta$-mercaptoethanol) by using a disposable micropestle. The homogenate was treated with proteinase $\mathrm{K}\left(200 \mu \mathrm{g} \mathrm{ml} \mathrm{H}^{-1}\right.$ extraction buffer) for $2 \mathrm{~h}$ at $65^{\circ} \mathrm{C}$, followed by RNase $\left(500 \mu \mathrm{g} \mathrm{ml}{ }^{-1}\right)$ treatment for another $2 \mathrm{~h}$ at $37^{\circ} \mathrm{C}$. The homogenate was then centrifuged at $12,000 \mathrm{rpm}$ for $4 \mathrm{~min}$ at room temperature, and the supernatant was extracted with an equal volume of chloroform: isoamyl alcohol $(24: 1)$ by centrifugation at $12,000 \mathrm{rpm}$ for $10 \mathrm{~min}$ to separate the phases. The aqueous phase was transferred to a clean tube, and the chloroform:isoamyl alcohol step was repeated. DNA was precipitated by the addition of an equal volume of chilled isopropanol to the aqueous phase and incubation at $4{ }^{\circ} \mathrm{C}$ for at least $30 \mathrm{~min}$. The precipitate was collected by centrifugation at $12,000 \mathrm{rpm}$ at $4^{\circ} \mathrm{C}$ for $15 \mathrm{~min}$, rinsed with $70 \%$ ethanol, air-dried and dissolved in $100 \mu \mathrm{l}$ of 1X TE buffer (10 mM Tris- $\mathrm{HCl}, \mathrm{pH} 8.0$, and $0.1 \mathrm{mM}$ EDTA). DNA quality and concentration were determined on $0.8 \%$ Tris borate-EDTA agarose gel (Sambrook et al., 1989) by using a known $\lambda$ concentration standard (Invitrogen, Carlsbad, California, USA).
Table 3. Selective primers used for AFLP analyses.

\begin{tabular}{llc}
\hline Primer ID & Code & Sequence \\
\hline $\mathrm{E}(\mathrm{N}+0+3)$ & E1 & GAC TGC GTA CCA ATT C AGG \\
$\mathrm{E}(\mathrm{N}+0+3)$ & E2 & GAC TGC GTA CCA ATT C ACA \\
$\mathrm{E}(\mathrm{N}+0+3)$ & E3 & GAC TGC GTA CCA ATT C ACT \\
$\mathrm{M}(\mathrm{N}+1+2)$ & $\mathrm{M} 1$ & GAT GAG TCC TGA GTA A CTA \\
$\mathrm{M}(\mathrm{N}+1+2)$ & $\mathrm{M} 2$ & GAT GAG TCC TGA GTA A CTT \\
$\mathrm{M}(\mathrm{N}+1+2)$ & $\mathrm{M} 3$ & GAT GAG TCC TGA GTA A CTG \\
$\mathrm{M}(\mathrm{N}+1+2)$ & $\mathrm{M} 4$ & GAT GAG TCC TGA GTA A CTC \\
$\mathrm{M}(\mathrm{N}+1+2)$ & $\mathrm{M} 5$ & GAT GAG TCC TGA GTA A CAG \\
$\mathrm{M}(\mathrm{N}+1+2)$ & $\mathrm{M} 6$ & GAT GAG TCC TGA GTA A CAC \\
$\mathrm{M}(\mathrm{N}+1+2)$ & $\mathrm{M} 7$ & GAT GAG TCC TGA GTA A CAA \\
$\mathrm{M}(\mathrm{N}+1+2)$ & $\mathrm{M} 8$ & GAT GAG TCC TGA GTA A CAT \\
\hline
\end{tabular}

\section{AFLP-PCR}

Template preparation and AFLP assay were performed using a modified protocol of Vos et al. (1995) with the incorporation of infrared fluorophore (IRD-700) (LI-COR, Lincoln, Nebraska, USA) labeled EcoRI primers in the PCR.

\section{Template preparation}

One microgram of genomic DNA was incubated with restriction endonucleases EcoRI (Invitrogen) and MseI (New 
A

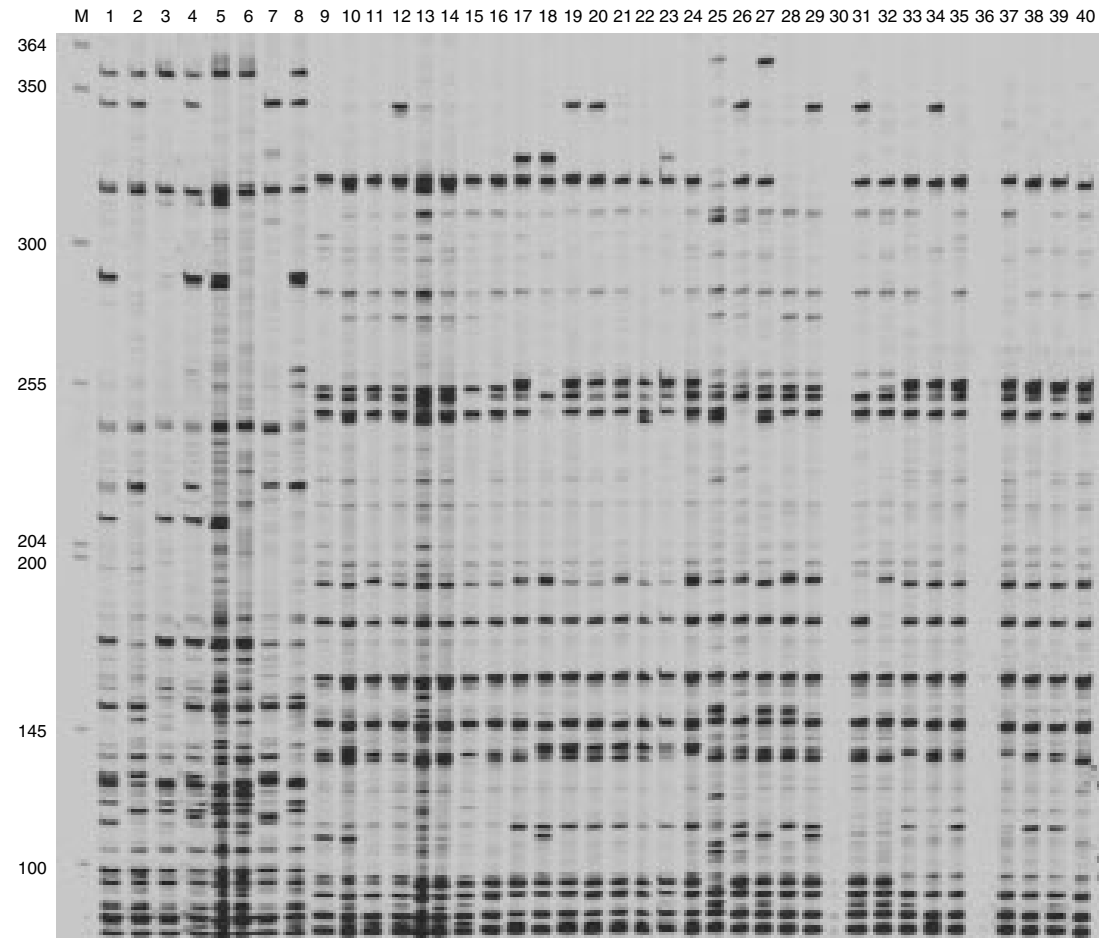

B

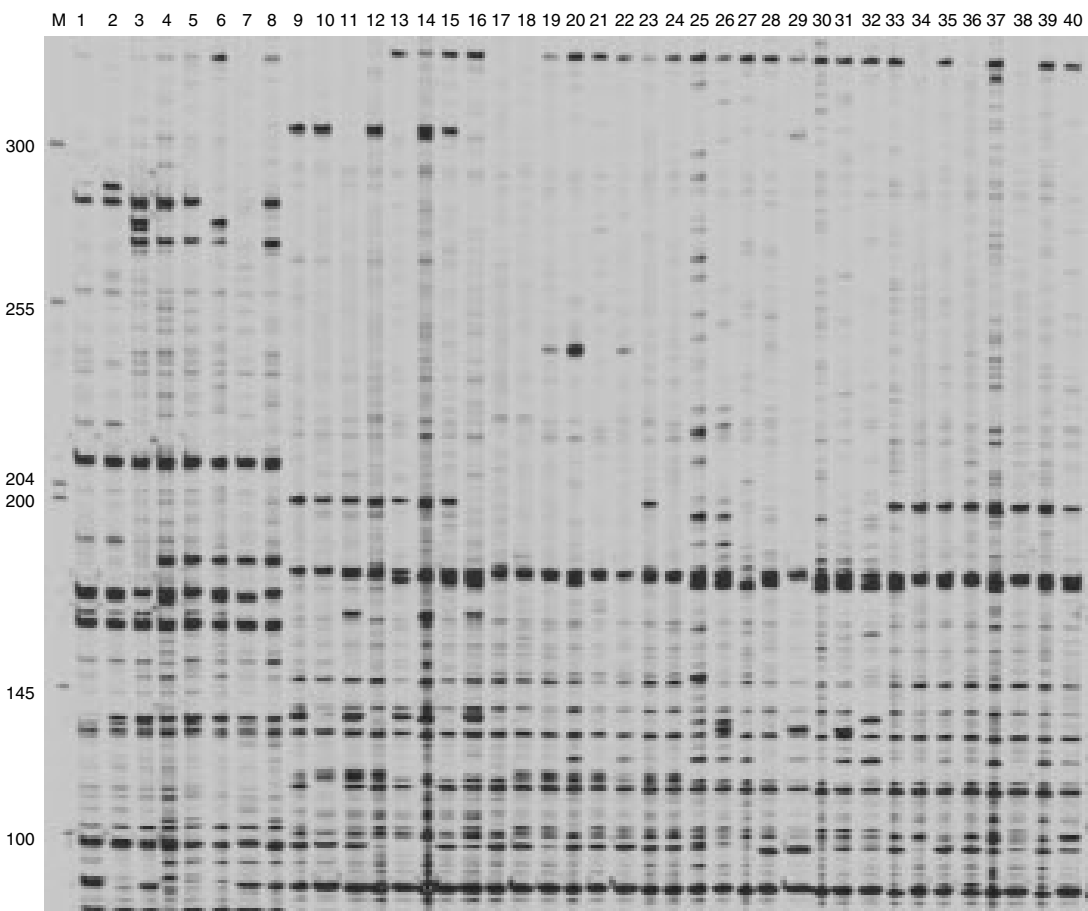

Fig. 1. AFLP fingerprints generated using primer combinations (a) E-AGG+M-CAA and (b) E-AGG + M-CAC from the genomic DNA of one population of C. macellaria, lanes (1-8) CM, and four populations of C. hominivorax, lanes (9-16) PN, (17-24) CR, (25-32) JA and (33-40) MX. Lane M contains the IRD-700 ladder (50-700 bp).

England Biolabs, Beverly, Massachusetts, USA) for $2.5 \mathrm{~h}$ at $37^{\circ} \mathrm{C}$ in a total volume of $12.5 \mu \mathrm{l}$ that contained $1.25 \mu \mathrm{l}$ of $10 \mathrm{X}$ One-Phor-All PLUS buffer (GE Healthcare, Little Chalfont, Buckinghamshire, UK), $0.32 \mu \mathrm{l}$ of $4 \mathrm{U}_{\mu l}^{-1}$ MseI enzyme
(1.25U per reaction), $0.08 \mu \mathrm{l}$ of $15 \mathrm{U}^{-1}$ EcoRI enzyme (1.25 $\mathrm{U}$ per reaction), and $0.125 \mu \mathrm{l}$ of $10 \mathrm{mg} \mathrm{ml}^{-1}$ bovine serum albumin (New England Biolabs); autoclaved nanopure water was added to make up the final volume of $12.5 \mu \mathrm{l}$. 
Table 4. Diagnostic AFLP bands for (a) interspecific and (b) intraspecific identification of screwworms.

(a)

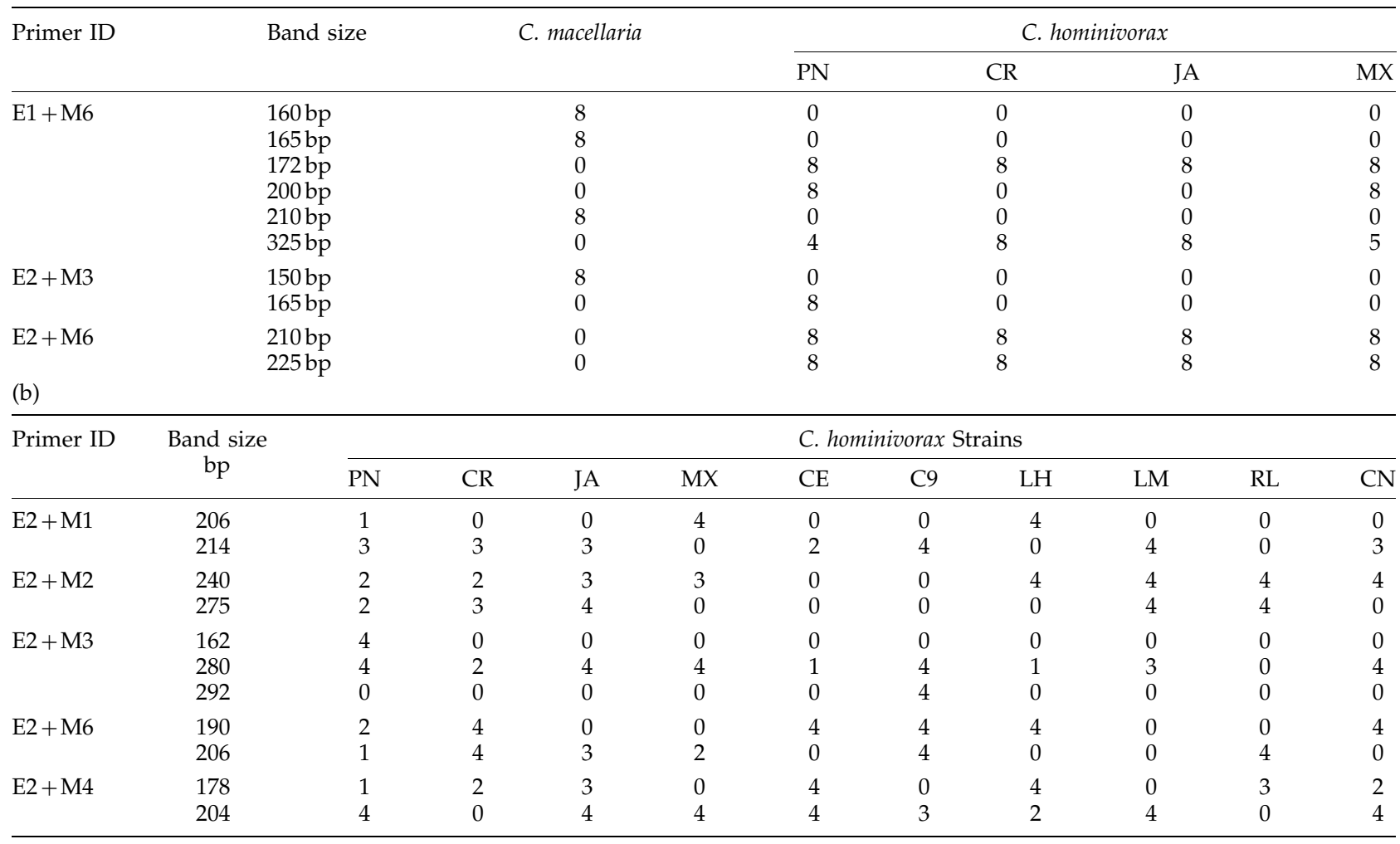

bp represents band size in base pairs; values below each strain represent the number of individuals displaying a band.

The restriction fragments were incubated for $6 \mathrm{~h}$ at room temperature $\left(\sim 25^{\circ} \mathrm{C}\right)$ with $5 \mu$ l of ligation mixture containing $0.5 \mu \mathrm{l}$ of 10X T4 DNA ligase buffer (Invitrogen), $0.5 \mu \mathrm{l}$ of 5 pmol $\mu \mathrm{l}^{-1}$ EcoRI adapter, $0.5 \mu \mathrm{l}$ of $50 \mathrm{pmol}^{-1} \mathrm{MseI}$ adapter, $0.150 \mu \mathrm{l}$ of T4 DNA ligase (catalog no. M0202S, New England Biolabs) and $3.350 \mu \mathrm{l}$ autoclaved nanopure water for ligating the adapters. Double-stranded adapters for the corresponding restriction enzymes were prepared by incubating equimolar amounts of both strands (EcoRI-F and EcoRI-R for EcoRI adapter and MseI-F and MseI-R for MseI adapter) (QIAGEN Operon, Alameda, CA) (table 2; sequences taken directly from Vos et al., 1995) for $10 \mathrm{~min}$ at $65^{\circ} \mathrm{C}, 10 \mathrm{~min}$ at $37^{\circ} \mathrm{C}$ and $10 \mathrm{~min}$ at $25^{\circ} \mathrm{C}$.

\section{AFLP assay}

Ligation was followed by 20 cycles of preselective PCR amplification $\left(30 \mathrm{~s}\right.$ at $94^{\circ} \mathrm{C}, 1 \mathrm{~min}$ at $56^{\circ} \mathrm{C}$ and $1 \mathrm{~min}$ at $72^{\circ} \mathrm{C}$ ) by using $1 \mu \mathrm{l}$ of adapted DNA diluted 10-fold with $1 \mathrm{X}$ TE buffer $(10 \mathrm{mM}$ Tris-Cl and $0.1 \mathrm{mM}$ EDTA, pH 8.0), $10 \mu \mathrm{l}$ of pre-amp primer mix II (contains two oligonucleotide primers, one primer corresponding to the EcoRI adaptedends and one primer corresponding to the MseI-ends) (Invitrogen), $1.25 \mu \mathrm{l}$ of $10 \mathrm{X}$ PCR buffer plus $15 \mathrm{mM} \mathrm{MgCl}_{2}$ and $0.25 \mu \mathrm{l}$ of $5 \mathrm{U}^{-1}$ AmpliTaq DNA polymerase (1.25U per reaction) (Applied Biosystems, Foster City, California, USA). The oligonucleotide primers in the pre-amp primer mix II are complementary to the adapter/restriction site with MseI primer containing one selective nucleotide $(M+1$ primer; table 2.) and EcoRI primer containing no selective nucleotide ( $\mathrm{E}+0$ primer; table 2). Products from preamplification reactions were diluted 20-fold with autoclaved nanopure water and were used as templates for further selective amplifications by using IRD-700 fluorophore-labeled EcoRI primer (LI-COR) with three selective nucleotides at the $3^{\prime}$ end $(E+0+3)$ and MseI primer with two additional nucleotides added at the $3^{\prime}$ end of $\mathrm{M}+1$ primer used earlier $(\mathrm{M}+1+2)$ (table 3).

Selective PCR amplifications were performed in a $12-\mu \mathrm{l}$ volume and contained $2.5 \mu \mathrm{l}$ of diluted preamplification product, $5.8 \mu \mathrm{l}$ of autoclaved nanopure water, $1.2 \mu \mathrm{l}$ of $10 \mathrm{X}$ PCR buffer containing $15 \mathrm{mM} \mathrm{MgCl}_{2}$ and $0.06 \mu \mathrm{l}$ of $5 \mathrm{U}_{\mu l}^{-1}$ AmpliTaq DNA polymerase (Applied Biosystems), $2.0 \mu \mathrm{l}$ of MseI primer $(\mathrm{M}+1+2)\left(6.7 \mathrm{ng} \mu \mathrm{l}^{-1}\right.$; dNTPs) (Invitrogen) and $0.5 \mu \mathrm{l}$ of $1.0 \mathrm{pmol}^{-1} \mathrm{l}^{-1}$ IRD-700-labeled EcoRI primer (LICOR). Selective amplifications were performed in a DNA thermal cycler 9600 (Applied Biosystems) by using the following touch-down PCR profile (Vos et al., 1995): one cycle of $30 \mathrm{~s}$ at $94^{\circ} \mathrm{C}, 30 \mathrm{~s}$ at $65^{\circ} \mathrm{C}$ and $1 \mathrm{~min}$ at $72^{\circ} \mathrm{C}, 12$ cycles of subsequently lowering annealing temperature $\left(65^{\circ} \mathrm{C}\right)$ by $0.7^{\circ} \mathrm{C}$ per cycle while keeping denaturation $\left(30 \mathrm{~s}\right.$ at $\left.94^{\circ} \mathrm{C}\right)$ and extension $\left(1 \mathrm{~min}\right.$ at $\left.72^{\circ} \mathrm{C}\right)$ temperature constant, 23 cycles of $30 \mathrm{~s}$ at $94^{\circ} \mathrm{C}, 30 \mathrm{~s}$ at $56^{\circ} \mathrm{C}$, and $1 \mathrm{~min}$ at $72^{\circ} \mathrm{C}$, and soak at $4^{\circ} \mathrm{C}$. After amplification, reactions were stopped by adding $2.5 \mu \mathrm{l}$ of blue stop solution (LI-COR), and the samples were denatured at $94^{\circ} \mathrm{C}$ for $5 \mathrm{~min}$ and flash cooled on ice immediately before electrophoresis. One microliter of the sample along with $1 \mu \mathrm{l}$ of IRD-labeled $50-700$-bp size marker (LI-COR) was electrophoresed through $\mathrm{KB}^{\text {Plus }} 6.5 \%$ ready-touse gel matrix (LI-COR), and the infrared fluorescent bands 


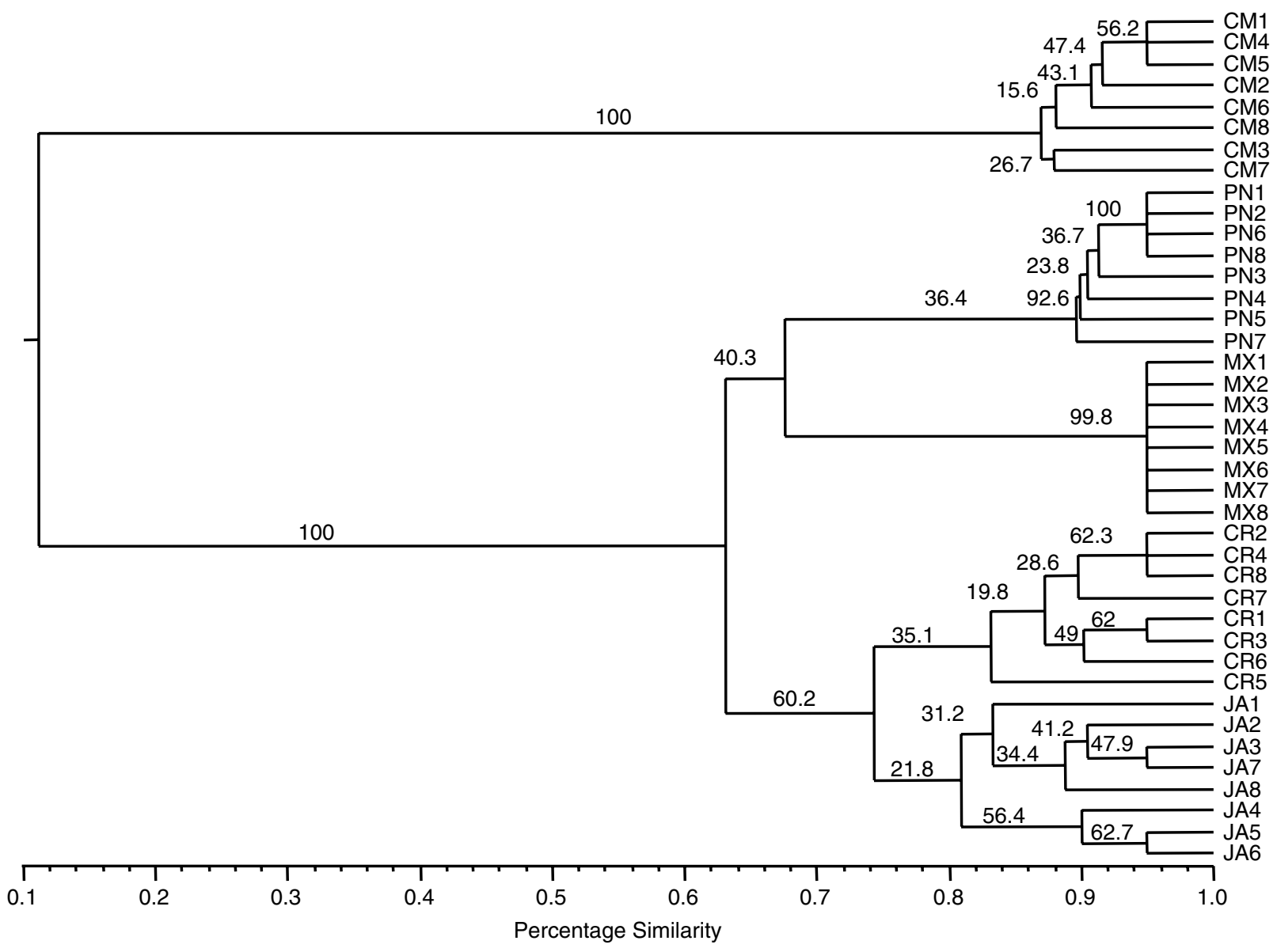

Fig. 2. Dendrogram showing interspecific relationship between screwworms, C. macellaria (CM) and C. hominivorax (PN, CR, JA and MX) based on data from ten AFLP primer combinations. Similarity values were calculated using the Jaccard coefficient, UPGMA clustering. Values on branches indicate bootstrap values.

were detected by the laser scanning system (model 4200S-2, LI-COR).

\section{Data scoring and analysis}

For statistical analysis of inter- and intraspecific genetic variation, we acknowledge the following assumptions: the genotypes at marker loci are in Hardy-Weinberg proportions; AFLP products segregate as dominant alleles in a Mendelian manner, with most variation at the AFLP loci being biallelic (+/-) with one band allele and one bandless allele (Haymer, 1994; Borowsky, 2001). Image data (16-bits) were automatically collected and simultaneously recorded during electrophoresis. Sizes of AFLP fragments were estimated by comparing to IRD-700-labeled 50-700-bp AFLP ladder (LI-COR). AFLP fragments were scored and analyzed using Gene ImagIR software, version 3.52 (LI-COR) and converted into numerical data as a matrix by assigning 1 (band present) and 0 (band absent).

Data were analyzed with the software NTSYS-pc (Numerical Taxonomy and Multivariate Analysis System, version 2.02) (Rohlf, 1997). Similarity, matrices were generated according to the methods of Jaccard (=Grower's; a/ $(\mathrm{a}+\mathrm{b}+\mathrm{c}))$, as well as Dice $(=$ Nei and $\mathrm{Li} ; 2 \mathrm{a} /(2 \mathrm{a}+\mathrm{b}+\mathrm{c}))-$ where ' $a$ ' is the number of fragments shared by two populations, ' $b$ ' is the number of fragments present only in one population and ' $c$ ' is the number of fragments present only in the other population - and results were compared (Sneath \& Sokal, 1973; Rohlf, 1997). Coefficients were computed using the SIMQUAL (similarity based on qualitative differences) program and a phenogram was generated by unweighted pair group method [UPGMA] by using arithmetic averages (Sokal \& Michener, 1958). The resulting cluster was represented as a dendrogram by using the sequential, agglomerative, hierarchical and nested (SAHN) clustering method. Bootstrapping (1000 replications) was performed using the Winboot program (Yap \& Nelson, 1996) to assess the strength of the clusters generated by the treemaking program and to test the consistency of the estimated relationships among individuals and populations (Felsenstein, 1985).

\section{Results}

\section{Interspecific discrimination of Cochliomyia spp.}

Four populations of $C$. hominivorax (PN, CR, JA and MX) and one population of $C$. macellaria (CM) (table 1) were used to screen ten primer combinations $(\mathrm{E} 1+\mathrm{M} 7, \mathrm{E} 1+\mathrm{M} 6$, $\mathrm{E} 2+\mathrm{M} 7, \mathrm{E} 2+\mathrm{M} 2, \mathrm{E} 2+\mathrm{M} 3, \mathrm{E} 2+\mathrm{M} 1, \mathrm{E} 2+\mathrm{M} 4, \mathrm{E} 2+\mathrm{M} 6$, 
Table 5. Comparison of the genetic similarity levels in populations of C. macellaria $(\mathrm{CM})$ and $C$. hominivorax (PN, CR, JA, MX, $\mathrm{CE}, \mathrm{C}$, $\mathrm{LH}, \mathrm{LM}, \mathrm{RL}$ and $\mathrm{CN}$ ) as calculated by the Jaccard and Dice coefficients for the interspecific (a) and intraspecific (b) studies.

(a)

\begin{tabular}{|c|c|c|}
\hline Species & $\begin{array}{c}\text { Jaccard } \\
\text { coefficient }(\%)\end{array}$ & $\begin{array}{c}\text { Dice } \\
\text { coefficient (\%) }\end{array}$ \\
\hline C. macellaria & 92 & 96 \\
\hline $\begin{array}{l}\text { C. hominivorax } \\
\text { (all populations) }\end{array}$ & 68 & 81 \\
\hline PN & 94 & 97 \\
\hline $\mathrm{CR}$ & 88 & 94 \\
\hline JA & 86 & 92 \\
\hline MX & 100 & 100 \\
\hline $\begin{array}{l}\text { Between CM and } \\
\text { C. hominivorax }\end{array}$ & 16 & 28 \\
\hline \multicolumn{3}{|l|}{ (b) } \\
\hline Strain & $\begin{array}{c}\text { Jaccard } \\
\text { coefficient (\%) }\end{array}$ & $\begin{array}{c}\text { Dice } \\
\text { coefficient }(\%)\end{array}$ \\
\hline $\mathrm{PN}$ & 75 & 86 \\
\hline CR & 73 & 84 \\
\hline JA & 78 & 88 \\
\hline MX & 89 & 94 \\
\hline CE & 88 & 94 \\
\hline C9 & 92 & 96 \\
\hline LH & 90 & 94 \\
\hline LM & 89 & 94 \\
\hline RL & 89 & 94 \\
\hline $\mathrm{CN}$ & 85 & 92 \\
\hline $\begin{array}{l}\text { Among all } \\
\text { strains }\end{array}$ & 58 & 74 \\
\hline
\end{tabular}

$\mathrm{E} 2+\mathrm{M} 5$ and E3+M8) (table 3). The two species C. hominivorax and C. macellaria were readily distinguished by their well-resolved AFLP banding patterns generated by all of the ten primer combinations tested (fig. 1). Two kinds of parameters were considered for this study: (i) the presence or absence of diagnostic bands (particularly those present only in C. macellaria and absent in C. hominivorax and/or vice versa); and (ii) the existence of a characteristic, reproducible pattern of AFLP-PCR products, revealing a potentially diagnostic profile for a particular geographical population. The ten primer combinations used generated a large number of fragments (10-35 bands per individual) that depended on the type of selective nucleotides used. For statistical analyses, 52 consistent and discrete, scorable bands were used: seven bands were monomorphic and were found in both species; 22 bands were specific for C. macellaria populations; of the remaining 23 bands, ten were found only in C. hominivorax and 13 bands were diagnostic for different geographical populations of C. hominivorax. The species-specific, as well as population-specific, diagnostic bands for Cochliomyia spp. discrimination and identification are listed in table 4 . Cluster analysis of similarity matrix (Jaccard coefficient) by UPGMA unambiguously separated the flies of each species into two major clusters that were only $16 \%$ similar. Also, bootstrap analyses showed $100 \%$ support for the branch separating the two species (fig. 2). Although both Jaccard and Dice coefficients generated similar clustering patterns, the resulting similarity values were slightly different (table 5a). Cochliomyia macellaria samples formed a distinct cluster, grouped together at the 92\% level. Within this cluster, the similarity values between individuals in the population varied (range 92-100\%). Cochliomyia hominivorax samples formed four distinct clusters, and bootstrap values among individuals within a population and between populations were variable (fig. 2). Populations from PN grouped together at the $94 \%$ level (range 94-100\%), populations from MX grouped at the $100 \%$ level, CR samples clustered together at the $88 \%$ level (range $88-100 \%$ ) and samples from JA grouped together at the $86 \%$ level. Within the C. hominivorax groupings, flies from $\mathrm{PN}$ and MX at the $72 \%$ level and CR and JA at $79 \%$ level were apparent. Populations of C. hominivorax from the four geographical locations grouped at the $68 \%$ level. Fly specimens from MX showed a high degree of similarity to each other $(100 \%)$, whereas flies from JA showed relatively higher heterogeneity compared with the other flies (fig. 2).

\section{Intraspecific discrimination of $\mathrm{C}$. hominivorax strains}

PCR amplification of DNA from the ten C. hominivorax strains (table 1) produced a discrete banding pattern (fig. 3) for each of the ten primer combinations tested $(\mathrm{E} 2+\mathrm{M} 1$, $\mathrm{E} 2+\mathrm{M} 2, \mathrm{E} 2+\mathrm{M} 3, \mathrm{E} 2+\mathrm{M} 6, \mathrm{E} 2+\mathrm{M} 4, \mathrm{E} 2+\mathrm{M} 5, \mathrm{E} 2+\mathrm{M} 7$, $\mathrm{E} 2+\mathrm{M} 8, \mathrm{E} 3+\mathrm{M} 7$ and E3+M8) (table 3). The number of bands generated by each primer pair ranged between ten and 20 and depended largely on the selective nucleotides used. For estimating intraspecific relationships among different screwworm strains, statistical analyses were performed using 72 bands composed of 19 monomorphic fragments (found in all C. hominivorax strains) and 53 polymorphic bands. Cluster analysis of similarity matrix (Jaccard coefficient) by UPGMA grouped all of the strains with a similarity level of $58 \%$. At the $85 \%$ similarity level, seven clusters (MX, LM, CN, LH, C9, CE and RL), representing mutant strains, were resolved; and, at the $72 \%$ similarity level, all ten clusters (representing ten strains) were resolved (fig. 4). PN flies grouped at the $75 \%$ similarity level, JA flies at the $78 \%$ level, MX flies at the $89 \%$, LM flies at the $89 \%$ level, $\mathrm{CN}$ flies at the $85 \%$ level, $\mathrm{LH}$ flies at the $90 \%$ level, C9 flies at the $92 \%$ level, CR flies at the $72 \%$ level, CE flies at the $88 \%$ level and RL flies at $89 \%$ level. Within the C. hominivorax strains, PN, JA and CR flies seemed to have a relatively lower level of similarity compared with the mutant strains from MX (table 5b) that had similarity levels greater than $85 \%$. Bootstrap values are presented for each strain and not for individuals within a strain (fig. 4). The bootstrap values for clusters representing individual strains were high, suggesting a strong cluster. However, clusters of different strains had a lower bootstrap value (fig. 4), suggesting a weak cluster. Additionally, compared with the previous study of interspecific relationships in screwworms, here we observed that JA strain flies grouped with MX (and not CR strain) at the $72 \%$ similarity level; and these two groups further clustred with PN flies at the $67 \%$ level. Strain-specific marker bands generated by AFLP primers are presented in table $4 \mathrm{~b}$.

\section{Discussion}

Genome fingerprinting with arbitrary primers is a versatile method for obtaining highly informative genetic markers in geographical populations of insects, and the information generated from such studies can be used for 


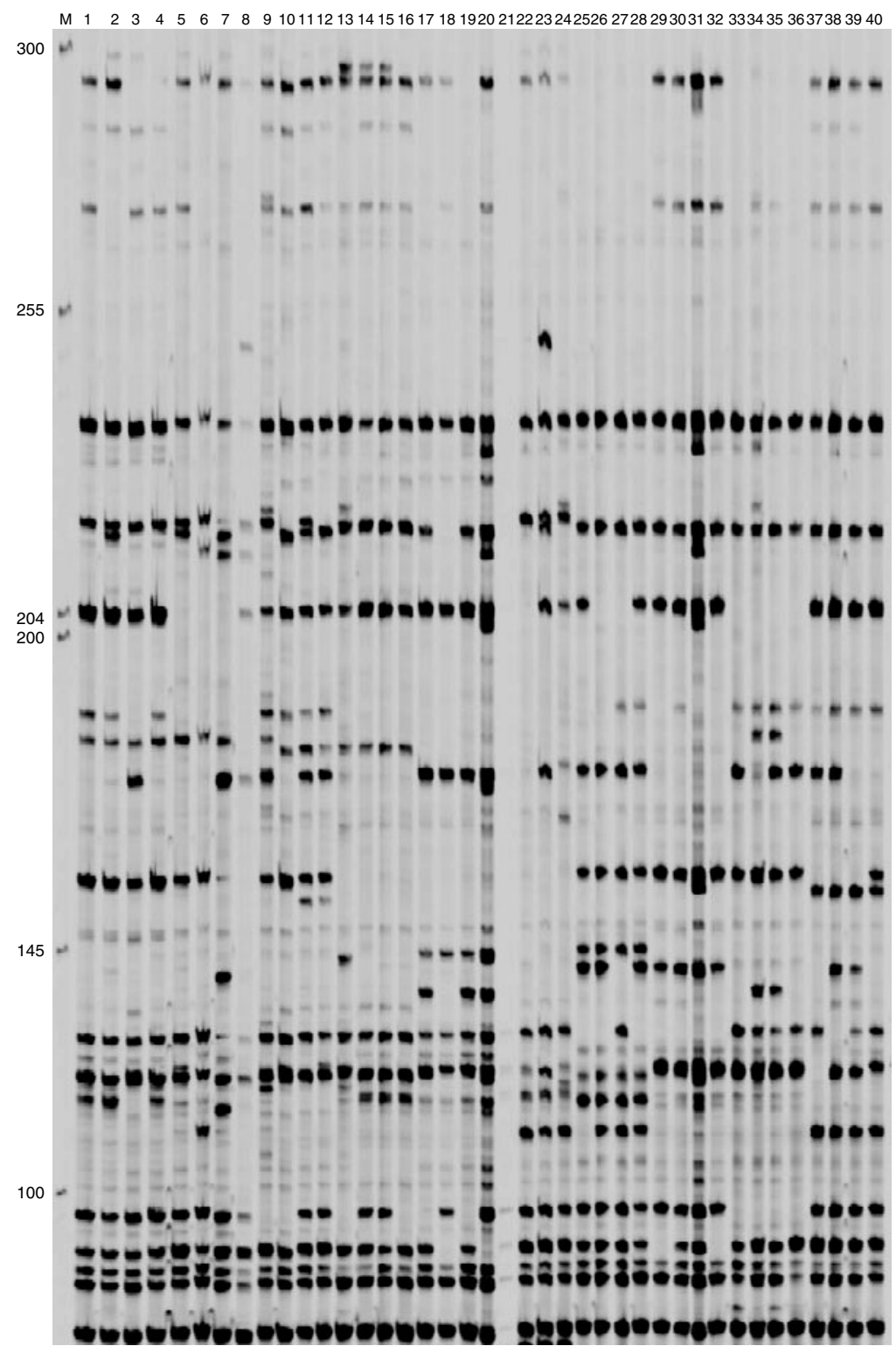

Fig. 3. AFLP fingerprints generated using primer combination E-ACA + M-CTC from the genomic DNA of ten strains of $C$. hominivorax: lanes (1-4) PN, (5-8) CR, (9-12) JA, (13-16) MX, (17-20) CE, (21-24) C9, (25-28) LH, (29-32) LM, (33-36) RL and (37-40) CN. Lane M contains IRD-700 ladder (50-700 bp).

tracking individuals, genes or both (Parker et al., 1998). As with random amplified polymorphic DNA (RAPD) (Welsh \& McClelland, 1990; Williams et al., 1990), the AFLP technique generates individual specific profiles from template DNA by amplifying anonymous fragments from sites scattered through the genome (Borowsky, 2001). However, AFLP differs from the RAPD method in technical detail and has several advantages, such as higher temperature stringency, resulting in more reliable, reproducible data (Majer et al., 1996; Maugham et al., 1996; Sanchez et al., 1998; Reineke et al., 1999). Similar to RAPD markers, AFLP produces dominant markers and also is affected by small changes in reaction conditions, such as buffer concentrations, quality and concentration of DNA, source and concentration of Taq polymerase enzyme, and amplification conditions (Cervera et al., 2000); therefore, we optimized several parameters as defined in 'Materials and methods'.

A primary requirement for the screwworm eradication program is the correct identification of species, because facultative and scavenger flies in the families Calliphoridae and Sarcophagidae may be attracted to necrotic wounds of animals, thereby confounding the identification dilemma in the early instars, especially by morphological observations (Hall \& Wall, 1995). On average, we identified at least 5-10 diagnostic bands per primer pair to discriminate C. hominivorax from $C$. macellaria. Observed differences in the banding patterns, low levels of similarity (16\%) and $100 \%$ support for the branch separating $C$. hominivorax from 


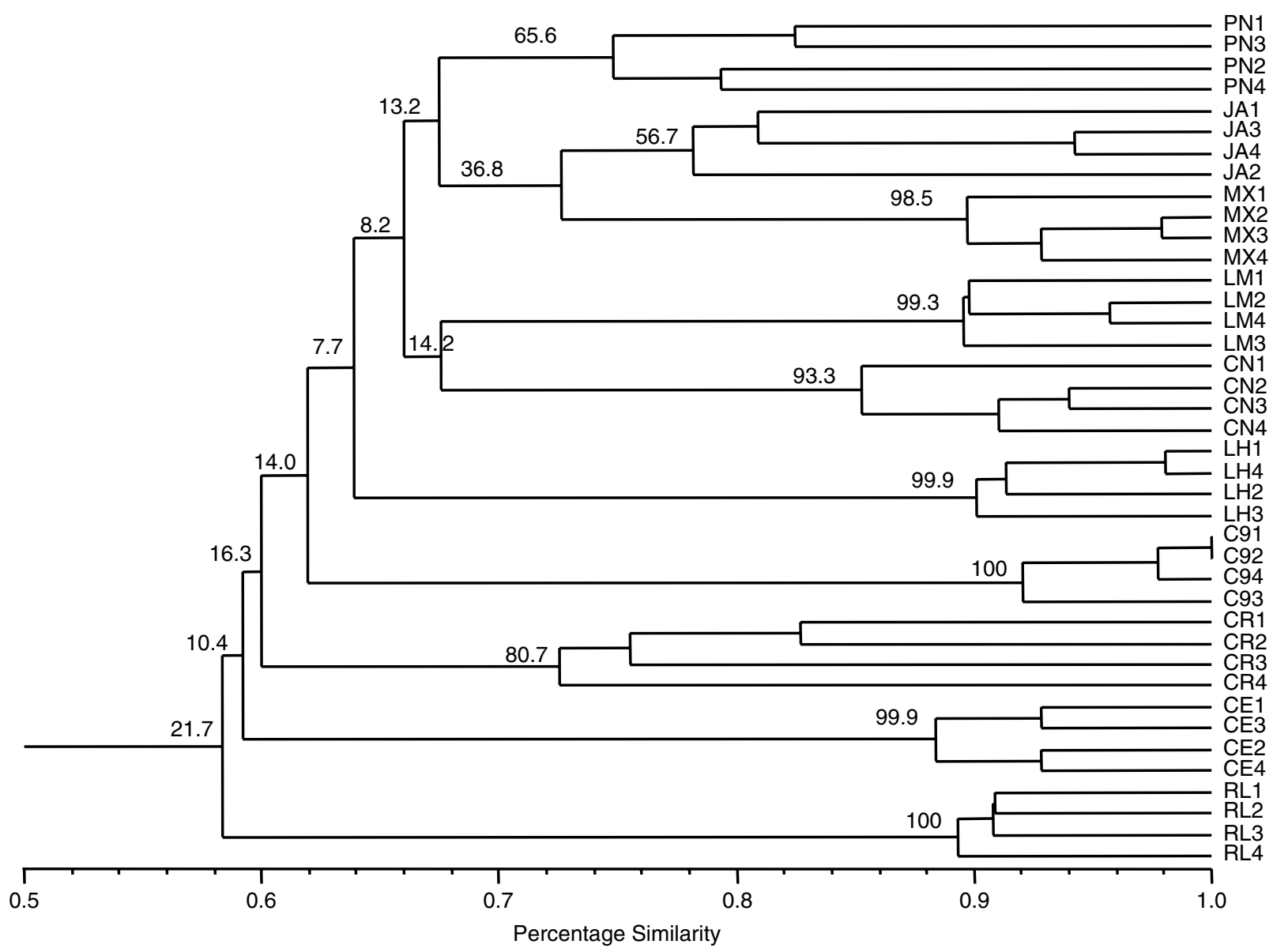

Fig. 4. Dendrogram showing intraspecific relationship among C. hominivorax populations (PN, CR, JA, MX, CE, C9, LH, LM, RL and $\mathrm{CN}$ ) based on data from ten AFLP primer combinations. Similarity values were calculated using the Jaccard coefficient, UPGMA clustering. Values on branches indicate bootstrap values.

C. macellaria indicate that the two species have considerable genetic differences and that AFLP is a good tool for rapid identification at the interspecific level (figs 1 and 2). Speciesspecific diagnostic bands were found (table 4a) that provide for discrimination of these species based on the presence or absence of some AFLP-PCR products. AFLP analysis yielded 10-35 bands per individual per primer combination, more than those detected either by RAPDs (Skoda et al., 2002) or PCR-RFLP of mitochondrial DNA (mtDNA) (Taylor et al., 1996), many diagnostic bands that may ultimately be used for characterizing C. hominivorax strains (table $4 \mathrm{~b}$ ).

The population genetics of screwworms explored in the intraspecific studies showed that flies from MX were more homogenous and had high percent similarity values and bootstrap support ( $>95 \%$ ). For example, MX flies grouped at the $100 \%$ similarity level (fig. 2) and $89 \%$ similarity level (fig. 4) in both studies, respectively. Also, other mutant strains originating from Mexico (CE, LH, LM, RL and CN) had $>85 \%$ similarity level, and the branches were well supported $(>95 \%)$ by bootstrap analysis, indicating low genetic variability (fig. 4). These results are consistent with the strains from MX (table 1) being the oldest of the screwworm strains examined (established as laboratory cultures in 1984-1985). Consistent with this observation is the relatively higher variability (lower percent similarity) of JA flies that represented the more recent (1998) establishment of the population from Jamaica as laboratory colonies. AFLP patterns for the earlier, interspecific studies indicated similarity between two populations, $\mathrm{PN}$ and $\mathrm{MX}$; whereas CR showed similarity with JA populations (fig. 2). However, in the intraspecific studies clustering between populations was not strong (fig. 4). This difference in the clustering may be caused by the small sample size for intraspecific studies as well as the difference in the primer pairs screened.

In general, within-population variability was low compared with between-population variability, suggesting population substructure in $C$. hominivorax. The relatively higher variability between populations probably occurred because different alleles were fixed in different populations during culture. These results are similar to results reported using RAPD-PCR (Skoda et al., 2002) on laboratory populations, as well as by Infante-Malachias et al. (1999) in screwworms from southeastern Brazil and Argentina. Population genetic studies of screwworms using protein electrophoresis indicated a low genetic differentiation in flies (Krafsur \& Whitten, 1993; Taylor \& Peterson, 1994), whereas mtDNA analyses revealed high genetic variability and low gene flow (Roehrdanz \& Johnson, 1988; Roehrdanz, 1989). As 
suggested by Taylor et al. (1996), the low level of genetic variation observed within screwworm populations can be caused by bottlenecking, especially when samples used in the analyses are obtained from colonies that were in the laboratory for $\geq 4$ years, as in this case. Microsatellite markers for screwworms, co-dominant and potentially highly polymorphic (Torres \& Azeredo-Espin, 2005), used along with AFLP, dominant but providing high numbers of markers, may provide additional resolution for assessing genetic variability in screwworms.

In conclusion, our study demonstrates that, despite certain limitations, AFLP-PCR analysis is a good tool for differentiating species and has tremendous potential for studies of intraspecific genetic variation; it is capable of elucidating relationships and may provide diagnostic markers that identify geographical populations of C. hominivorax. Also, diagnostic bands could be isolated from the gels and sequenced so that specific primers can be generated and then used to determine the geographical origin of an outbreak or infestation. In addition, these markers can be used effectively to screen strains for quality control in massrearing facilities.

\section{Acknowledgements}

The authors wish to thank Dennis Berkebile for providing the samples used in this research and, along with David Carter, useful comments provided on an early draft. This work was part of Coordinated Research Project IAEA-314D4-RC.851.1. This article reports the results of research; mention of a proprietary product does not constitute endorsement or recommendation for its use by USDA.

\section{References}

Anonymous (1990) Suspected screwworms in Texas. Texas A\&M Agricultural Experiment Station, Foreign Animal Disease Report 18, 4 .

Avise, J.C. (1994) Molecular Markers, Natural History and Evolution. 511 pp. New York, Chapman \& Hall.

Bensch, S. \& Åkesson, M. (2005) Ten years of AFLP in ecology and evolution: why so few aminals? Molecular Ecology 14, 2899-2914.

Black IV, W.C. \& Duteau, N.M. (1997) RAPD-PCR and SSCP analysis for insect population genetic studies. pp. 361-373 in Crampton, J.M., Beard, C.B. \& Louis, C. (Eds) The Molecular Biology of Insect Disease Vectors: A Methods Manual. New York, Chapman \& Hall.

Borowsky, R.L. (2001) Estimating nucleotide diversity from random amplified polymorphic DNA and amplified fragment length polymorphism data. Molecular Phylogenetics and Evolution 18, 143-148.

Bram, R.A. (1985) Future screwworm eradication programs. pp. 37-40 in Graham, O.H. (Ed.) First Symposium on Eradication of the Screwworm from the United States and Mexico. Entomological Society of America, 9-13 December 1984, College Park, MD, USA.

Cervera, M.T., Cabezas, J.A., Simon, B., Martinex-Zapater, J.M., Beitia, F. \& Cenis, J.L. (2000) Genetic relationships among biotypes of Bemisia tabaci (Hemiptera: Aleyrodidae) based on AFLP analysis. Bulletin of Entomological Research 90, 391396.
Chermette, R. (1989) A case of otitis due to screwworm, Cochliomyia hominivorax, in France. Veterinary Records 124, 641 .

Clark, P.L., Molina-Ochoa, J., Martinelli, S., Skoda, S.R., Isenhour, D.J., Krumm, J.T. \& Foster, J.E. (2007) Population variation of the fall armyworm, Spodoptera frugiperda, in the Western Hemisphere. Journal of Insect Science 7, 10 pp. Available online at http://www.insect science.org/7.05/.

Felsenstein, J. (1985) Confidence limits of phylogenies: an approach using the bootstrap. Evolution 39, 783-791.

Figarola, J.L., Skoda, S.R., Berkebile, D.R. \& Foster, J.E. (2001) Identification of screwworms, Cochliomyia hominivorax (Coquerel) (Diptera: Calliphoridae), with a monoclonal antibody-based enzyme-linked immunosorbent assay (MAb-ELISA). Veterinary Parasitology 102, 341-354.

Food and Agriculture Organization of the United Nations (1992) The New World screwworm eradication program: North Africa 1988-1992. Rome, Italy, FAO.

Hall, M.J.R. \& Beesley, W.N. (1990) The New World screwworm fly in North Africa. Pesticide Outlook 1, 34-37.

Hall, M.J.R. \& Wall, R. (1995) Myiasis of humans and domestic animals. Advances in Parasitology 35, 257-334.

Haymer, D.S. (1994) Random amplified polymorphic DNA and microsatellites. What are they and can they tell us anything we don't really know? Annals of the Entomological Society of America 87, 717-722.

Infante-Malachias, M.E., Yotoko, K.S.C. \& Azeredo Espin, A.M.L. (1999) Random amplified polymorphic DNA of screwworm fly populations (Diptera: Calliphoridae) from Southeastern Brazil and Northern Argentina. Genome 42, 772-779.

Katiyar, S.K., Chandel, G., Tan, Y., Zhang, Y., Huang, B., Nugaliyadde, L., Fernando, K., Bentur, J.S., Inthavong, J., Constantino, S. \& Bennett, J. (2000) Biodiversity of Asian gall midge (Orseolia oryzae Wood Mason) from five countries examined by AFLP analysis. Genome 43, 322-332.

Krafsur, E.S. \& Whitten, C.J. (1993) Breeding structure of screwworm fly populations (Diptera: Calliphoridae) in Colima, Mexico. Journal of Medical Entomology 30, 477480.

Leite, A.C.R. \& Guevara, J.D.E. (1993) Scanning electron microscopy of the larval instars of Cochliomyia hominivorax. Medical and Veterinary Entomology 7, 263-270.

Leung, H., Nelson, R.J. \& Leach, J.E. (1993) Population structure of plant pathogenic fungi and bacteria. Advances in Plant Pathology 10, 157-205.

Litjens, P., Lessinger, A.C. \& de Azeredo-Espin, A.M. (2001) Characterization of the screwworm flies Cochliomyia hominivorax and Cochliomyia macellaria by PCR-RFLP of mitochondrial DNA. Medical and Veterinary Entomology 15, 183-188.

Majer, D., Mithen, R., Lewis, B., Vos, P. \& Oliver, R. (1996) The use of AFLP fingerprinting for the detection of genetic variation in fungi. Mycological Research 100, 11071111.

Maugham, P.J., Saghai-Maroof, M.A., Buss, G.R. \& Huestis, G.M. (1996) Amplified fragment length polymorphism (AFLP) in soybean: species diversity, inheritance and near-isogenic line analysis. Theoretical and Applied Genetics 93, 392-401.

McMichael, M. \& Pashley, P.D. (1999) Differences in amplified fragment length polymorphisms in fall armyworm 
(Lepidoptera: Noctuidae) host strains. Annals of the Entomological Society of America 92, 175-181.

Narang, S.K. \& Degrugillier, M.E. (1995) Genetic fingerprinting of the screwworm (Diptera: Calliphoridae) infestation in North Africa by mitochondrial DNA markers. Florida Entomologist 78, 294-304.

Parker, P.G., Snow, A.A., Schug, M.G., Booton, G.C. \& Fuerst, P.A. (1998) What molecules can tell us about populations: choosing and using a molecular marker. Ecology 79, 361382.

Reineke, A., Karlovsky, P. \& Zebitz, C.P.W. (1999) Amplified fragment length polymorphism analysis of different geographic populations of the gypsy moth, Lymantria dispar (Lepidoptera: Lymantriidae). Bulletin of Entomological Research 89, 79-88.

Roderick, G.K. (1996) Geographic structure of insect populations: gene flow, phylogeography and their uses. Annual Review of Entomology 41, 325-352.

Roehrdanz, R.L. (1989) Intraspecific genetic variability in mitochondrial DNA of the screwworm fly (Cochliomyia hominivorax). Biochemical Genetics 27, 551-569.

Roehrdanz, R.L. \& Johnson, D.A. (1988) Mitochondrial DNA variation among geographical populations of the screwworm fly, Cochliomyia hominivorax. Journal of Medical Entomology 25, 136-141.

Rohlf, F.J. (1997) NTSYS-pc: numerical taxonomy and multivariate analysis system. Version 2.02. Setauket, NY, Exeter Publishing Ltd.

Sambrook, J., Fritsch, E.F. \& Maniatis, T. (1989) Molecular cloning: a laboratory manual, vol. 1. Plainview, NY, Cold Spring Harbor Laboratory Press.

Sanchez, G., Restrepo, S., Duque, M.-C., Fregene, M., Bonierbale, M. \& Verdier, V. (1998) AFLP assessment of genetic variability in cassava accessions (Manihot esculenta) resistant and susceptible to the cassava bacterial blight (CBB). Genome 42, 163-172.

Searson, J., Sanders, L., Davis, G., Tweddle, N. \& Thornber, P. (1992) Screw-worm fly myiasis in an overseas traveler-case report. Communicable Disease Intelligence 16, 239-240.

Sneath, P.H.A. \& Sokal, R.R. (1973) Numerical taxonomy. 573 pp. San Francisco, CA, Freeman Press.

Skoda, S.R., Pornkulwat, S. \& Foster, J.E. (2002) Random amplified polymorphic DNA markers for discriminating
Cochliomyia hominivorax from C. macellaria (Diptera: Calliphoridae). Bulletin of Entomological Research 92, 89-96.

Sokal, R.R. \& Michener, C.D. (1958) A statistical method for evaluating systematic relationships. University of Kansas Science Bulletin 38, 1409-1438.

Suazo, A. \& Hall, H.G. (1999) Modification of the AFLP protocol applied to honey bee (Apis mellifera L.) DNA. Biotechniques 26, 704-705, 708-709.

Taylor, D.B. \& Peterson II, R.D. (1994) Population genetics and gene variation in primary and secondary screwworm (Diptera: Calliphoridae). Annals of the Entomological Society of America 87, 626-633.

Taylor, D.B., Szalanski, A.L. \& Peterson II, R.D. (1996) Mitochondrial DNA variation in screwworm. Medical and Veterinary Entomology 10, 161-169.

Torres, T.T. \& Azeredo-Espin, A.M.L. (2005) Development of new polymorphic microsatellite markers for the New World screwworm Cochliomyia hominivorax (Diptera: Calliphoridae). Molecular Ecology Notes 5, 815-817.

Vargas-Terán, M., Hofmann, H.C. \& Tweddle, N.E. (2005) Impact of screwworm eradication programmes using the sterile insect technique. pp. 629-650 in Dyck, V.A., Hendrichs, J. \& Robinson, A.S. (Eds) Sterile Insect Technique: Principles and Practices in Area-wide Integrated Pest Management. The Netherlands, Springer.

Vos, P., Hogers, R., Bkeeker, M., Reijans, M., van de Lee, T., Horner, M., Frijters, A., Pot, J., Peleman, J., Kuiper, K. \& Zabeau, M. (1995) AFLP: a new technique for DNA fingerprinting. Nucleic Acids Research 23, 4407-4414.

Welsh, J. \& McClelland, M. (1990) Fingerprinting genomes using PCR with arbitrary primers. Nucleic Acids Research 18, 7213-7218.

Williams, J.G.K., Kubelik, A.R., Livak, K.J., Rafalski, J.A. \& Tingey, S.V. (1990) DNA polymorphisms amplified by arbitrary primers are useful as genetic markers. Nucleic Acids Research 18, 6531-6535.

Wyss, J.H. \& Galvin, T.J. (1996) Central America regional screwworm eradication program (benefit/cost study). Annals of the New York Academy of Sciences 791, 241-247.

Yap, I. \& Nelson, R.J. (1996) WinBoot: a program for performing bootstrap analysis of binary data to determine the confidence limits of UPGMA-based dendrograms. IRRI Discussion Paper Series No. 14. International Rice Research Institute, Manila, Philippines. 